\title{
Decision on Halal Certification of Food and Beverage Products Processed by UMKM Products in Tangerang City - Study of Religiosity, Regulation and Branding
}

\author{
Aulia Ramadhan ${ }^{1 *}$, Edy Yusuf Agung Gunanto ${ }^{2)}$ \\ ${ }^{1,2}$ Fakultas Ekonomika dan Bisnis, Universitas Diponegoro \\ *Email korespondensi: auliaramadhan298@gmail.com
}

\begin{abstract}
The city of Tangerang with the motto akhlakul karimah and the majority of the population is Muslim, which is $1,587,270$ or $88.25 \%$, so it pays great attention to the halalness of the products in circulation. The government requires that every product that enters, circulates, and is traded in the territory of Indonesia must be halal certified, including products of Micro, Small, and Medium Enterprises (MSMEs). There are 11,746 MSMEs in Tangerang City and the leading sectors that can be developed are the service sector and manufacturing industry. This study aims to determine the effect of economic factors, religiosity, socio-culture, regulation, and branding on the decision of MSMEs to carry out halal certification. This study uses primary data with a data collection method in the form of a questionnaire. The population in this study is UMKM which has been halal certified with the facilitation of the Tangerang City Government in 2019. The population is 100 MSMEs and 80 MSMEs are sampled. This study uses multiple linear regression analysis is processed using SPSS version 22. The results of the analysis of this study indicate that the most dominant variable partially has a positive and significant effect on the decision of MSMEs to carry out halal certification is branding. This proves that the halal label can be used as a good image for MSMEs to consumers. The variables that partially have a positive and significant effect on the decision of MSMEs to carry out halal certification, then, are religiosity and regulation. Meanwhile, the socioculture and economy partially do not affect the decision of MSMEs to carry out halal certification. Simultaneously, the results obtained are that economy, religiosity, socio-culture, regulation, and branding affect the decision of MSMEs to carry out halal certification.
\end{abstract}

Keywords: Economy, religiosity, social culture, regulations, branding, and halal certification

Saran sitasi: Ramadhan, A., Gunanto, E. Y. A. (2021). Decision on Halal Certification of Food and Beverage Products Processed by UMKM Products in Tangerang City - Study of Religiosity, Regulation and Branding. Jurnal Ilmiah Ekonomi Islam, 7(02), 786-797. doi: http://dx.doi.org/10.29040/jiei.v7i2.2490

DOI: http://dx.doi.org/10.29040/jiei.v7i2.2490

\section{INTRODUCTION}

Indonesia has a population of more than 237 million people in 2010 . The population on the census has conducted by the Central Statistics Agency (BPS) in 2010 showed that the number of people who are Muslim is $87.18 \%$ of the total population in Indonesia or 207 million people. Indonesia with the largest Muslim population in the world will certainly influence people's consumption behavior towards a product.

Halal is a standard that must require in Islam. Halal in language comes from the root word الحل which means (الإباحة) which means something that is allowed according to sharia (Ali, 2016). Halal is not only seen from the visible form, but it requires an indepth test on objects that are considered halal to confirm whether the content and processing method is halal or not. Food and beverages that are currently produced are processed through a process. Processed food according to Law No. 7 of 1996 concerning Food said that processed food is food and beverage which processed by certain methods with or without additives. 
The Fiscal Policy Agency (BKF) Ministry of finance (2019) issued a report for the 3rd quarter of 2019 which said that the manufacturing sector which grew by $4.15 \%$ year on year from the 3rd quarter of 2018 was dominated by the garment industry at $15.1 \%$, food and beverages by $8.33 \%$, and furniture by $6.93 \%$. Other industries experienced a contraction, such as the transportation equipment industry by $1.23 \%$, machinery and equipment by $-6.7 \%$, and oil and gas and coal by $-0.74 \%$. The food and beverage industry is in the second-largest position in the growth of the manufacturing industry sector, so care is needed in the production process to meet community needs and comply with standards. Producers of food and beverage production are not only carried out by corporations but Micro, Small, and Medium Enterprises (MSMEs) also have a share in the production of food and beverages.

Law No. 20 of 2008 explains that MSMEs are small companies or owned by a small group of people with a certain amount and income. The criteria for a business can be required to be MSMEs or large industries are determined based on assets and turnover. These criteria are as follows:

Table 1. 1 Business Criteria Based on Asstets and Turnover

\begin{tabular}{|c|c|c|}
\hline \multirow[b]{2}{*}{$\begin{array}{c}\text { Size of } \\
\text { Business }\end{array}$} & \multicolumn{2}{|c|}{ Criteria } \\
\hline & $\begin{array}{c}\text { Asset } \\
\text { (Excluding land \& } \\
\text { buildings) }\end{array}$ & $\begin{array}{c}\text { Turnover } \\
\text { (Within } 1 \text { year) }\end{array}$ \\
\hline Micro & $\begin{array}{l}\text { Maximum IDR } 50 \\
\text { million }\end{array}$ & IDR \\
\hline Small & $\begin{array}{l}\text { More than IDR } 50 \\
\text { million - IDR } 500 \\
\text { million }\end{array}$ & $\begin{array}{l}\text { IDR } \\
\text { on - } \\
\text { illion }\end{array}$ \\
\hline Medium & $\begin{array}{l}\text { More than IDR } 500 \\
\text { million - IDR } 10 \text { billion }\end{array}$ & $\begin{array}{l}\text { More than IDR } \\
2,5 \text { billion - } \\
\text { IDR } 50 \text { billion }\end{array}$ \\
\hline Large & $\begin{array}{l}\text { More than IDR } 10 \\
\text { billion }\end{array}$ & $\begin{array}{l}\text { More than IDR } \\
50 \text { billion }\end{array}$ \\
\hline
\end{tabular}

Source: (Ministry of Cooperatives and SMEs), Processed.

In 2018 there were 64,194,057 MSMEs in Indonesia and 5,550 large businesses (KEMENKOPUKM, 2018). MSMEs have a share of 99.9\% in the business sector, which means that the influence of MSMEs is huge in providing products to the needs of the community, especially food and beverage products. MSMEs with a huge portion in the production of food and beverages must ensure the halalness of their products.

To find if a product is guaranteed to be halal is by doing the halal certification. Halal certification is a way to determine whether an object is halal or haram in the form of a product. Certification is needed to avoid Syubhat. Syubhat is something that not clear about its halalness and prohibition because many people do not know the law.

BPJPH is the party that provides halal certification based on the decision to determine halal products from the Indonesian Ulema Council (MUI) which has previously been examined by the Halal Inspection Agency (LPH). Law Number 33 of 2014 Article 4 said that products that entered, circulated, and traded must be halal certified. Halal certification is an obligation that must be required by food and beverage producers to produce.

Regulations that make halal certification an obligation are one of the reasons food and beverage manufacturers carry out halal certification. In addition, by carrying out halal certification, producers will get a halal label in the form of a halal logo to assign that their products have received halal certification. The halal logo is part of the image or branding of food and beverage producers.

Halal branding owned by producers has implications for increasing public confidence in buying products owned by producers. Hill (in Hanim Yusuf et al., 2016) said that halal products are in high demand because Islam is currently the second-largest religion in the world. A large market will affect turnover.

Decision-making to carry out halal certification in Indonesia is also determined by the awareness of religion or religiosity from the producers because Indonesia in the first precept in Pancasila upholds religious values with the sound of "one Godhead." Rahmat (in Astogini et al., 2011)explains that religiosity is one's appreciation of one's religion which involves symbols, beliefs, values, and behaviors that are driven by spiritual forces.

The decision to carry out halal certification for producers is also determined by the socio-culture of the Indonesian people, which is a country with the largest Muslim population in the world. However, the population of Indonesia is very diverse in terms of culture and religion. Delbert Hawkins (in Nursinta Harmaniar, 2016) says demography is a population based on the number of people in a community, the 
structure of society (including gender, income, education, and income), and distribution, namely physical geographic location. Demographics in an area affect social relations, values, and norms adopted by the community in behavior and attitudes, including in making decisions to carry out halal certification for processed food and beverage products.

Tangerang City with motto Akhlakul Karimah and based on Law Number 33 of 2014 concerning Guarantee of Halal Products, the Tangerang City Government provides halal certification assistance to MSMEs in Tangerang City to ensure that MSME products are halal. The leading sectors that can be developed by MSMEs in Tangerang City are the service sector and the processing industry (Susila, 2013). In 2018 the number of MSMEs in Tangerang City was 11,746 consisting of the following scales:

Tabel 1.2 Number of MSMEs in Tangerang City

\begin{tabular}{ll}
\hline Size of Business & Number \\
\hline Micro & 11.079 \\
Small & 633 \\
Medium & 34 \\
\hline Total & 11.746
\end{tabular}

Source: Dinas Koperasi dan UKM Provinsi Banten, 2018, Processed.

In 2019, 100 MSMEs were given halal certification assistance from the Tangerang City Government. This figure is still far from being able to reach all halal-certified MSMEs. Halal certification can be made independently by MSMEs but for some producers, it's deemed unattainable. On the other hand, by carrying out halal certification, the opportunities that MSMEs have are wider open.

This study seeks to look at the determinants that influence the decisions of processed food and beverage producers. The determinants determined by the author are economy, religiosity, socio-culture, regulation, and branding.

\section{RESEARCH METHODS}

The dependent variable in this study is the decision of UMKM halal certification, while the independent variable is economy, religiosity, socioculture, regulation, branding. The population in this study were MSMEs that received free halal certification in 2019 from the Tangerang City Industry, Trade, Cooperative, and SME Service (DISPERINDAGKOPUKM), namely 100 MSMEs. Sampling was done using the purposive sampling technique, the number of which was taken was 80 SMEs. The data collection method in this study uses a questionnaire method with literature studies from journals, the internet, and books. The type of data in this study is quantitative. The data analysis used was the validity and reliability test, multiple linear regression, t-test, $F$ test, and coefficient of determination (R2).

\section{RESEARCH RESULTS AND DISCUSSION}

\subsection{Research Results}

\section{Respondents Overview}

The following is an overview of respondents based on various criteria:

a. The majority of respondents based on gender are female with a total of 59 people or $73.75 \%$ of the total respondents of 80 people. Meanwhile, the number of male respondents was 21 people or $26.25 \%$.

b. Respondents based on the majority age in generation $\mathrm{X}$ or range 40-55 years, amounting to 47 people or $58.75 \%$. The youngest respondent in this study was 21 years old and the oldest was 62 years old. When calculated in more detail, the average age of the respondents is 41.9 years, which is still in the productive age.

c. Respondents based on religion the majority of respondents are Muslim, amounting to 79 people or $98.75 \%$. The rest are Christians, amounting to 1 person or $1.25 \%$.

d. Respondents based on the majority of their education have high school education with a total of 29 people or $36.25 \%$. Followed by respondents whose education level is $\mathrm{S} 1$, amounting to 25 people or $31.25 \%$, D3 amounting to 17 people or $21.25 \%$, junior high school with 5 people or $6.25 \%$, and SD and S2 with 2 people or 2.5 respectively. $\%$.

e. The majority of respondents based on the subdistrict are from Karawaci District with a total of 15 people or $18.75 \%$. The rests are Cipondoh District with 11 people or $13.75 \%$, Batu Ceper and Karang Tengah with 9 people or 11.25 each. \%, Ciledug amounted to 8 people or $10 \%$, Pinang and Tangerang each numbered 7 people or $8.75 \%$, Cibodas numbered 6 people or $7.5 \%$, Jatiuwung numbered 4 people or $5 \%$, Neglasari 2 people or $2.5 \%$, and the last is the Prohibition and Pot, each of which amounts to 1 person or $1.25 \%$. Of the 13 sub-districts, only 1 sub-district without UMKM 
has received free halal certification, namely Benda District.

f. Respondents based on the majority of products produce food products with the number of respondents 62 people or $77.5 \%$. The rest were respondents who produced drinks, amounting to 18 people or $22.5 \%$.

g. Respondents based on turnover show that the majority of respondents have a turnover per month of $\leq 10$ million with a total of 58 people or $72.5 \%$. The highest respondent's turnover was IDR $100,000,000$ and the lowest was IDR 300,000. The average turnover of respondents when calculated is Rp. 5,611,250 and if it is calculated in 1 year, it is Rp. 67,335,000. With an average turnover of respondents for a year of $\mathrm{Rp}$. $67,335,000$, it means that the average business respondent is a micro-scale business because the annual turnover is less than Rp. 300,000,000. Although the average respondent's business is on a micro-scale, some respondents have included small-scale businesses (minimum annual turnover of Rp. 300,000,000) whose monthly turnover is $\geq$ Rp. 25,000,000. When calculated for a year, the amount is IDR $300,000,000$, which means that out of 80 respondents there are 14 small-scale business actors.

h. Respondents based on the length of business before halal certification mostly in $\leq 5$ years with a total of 71 people or $88.75 \%$. Respondents with the longest business length with 23 years before halal certification. While the shortest duration is
0 , which means that the respondent establishes a business at the same time as applying for the halal certification of his business.

i. Respondents based on the length of business after the majority of halal certification for 7 months, in which the halal certificate was issued in November 2019 amounting to 43 people or $53.75 \%$. The rest are respondents who have been in business for a long time after halal certification for 14 months in which the halal certificate was issued in April 2019, amounting to 37 people or $46.25 \%$.

j. Respondents based on the reasons for halal certification, the majority answered that the branding variable was the reason most respondents chose to do halal certification with a percentage of $27.57 \%$ or 51 people. Followed by regulations of $24.32 \%$ or 45 people, the economy of $20.54 \%$ or 38 people, the religiosity of $16.22 \%$ or 30 people, and socio-culture of $11.35 \%$ or 21 . Respondents can choose reasons individually or in combination.

\subsection{Discussion}

\section{Validity and Reliability Test}

The validity test is done to see whether an indicator is valid or not in a questionnaire. An indicator is said to be valid if the $r$ count is greater than the $r$ table with a significance level of 0.05 or $5 \%$. This study with 80 respondents, it is obtained $r$ table of 0.218 . The following are the results of the validity test as follows:

Table 1 The Result of Validity Test

\begin{tabular}{|lcccc|}
\hline \multicolumn{1}{c}{ Variable Indicators } & $\begin{array}{c}\text { Pearson } \\
\text { Correlations }\end{array}$ & $\begin{array}{c}\text { Sig } \\
\text { (2 tailed) }\end{array}$ & $\begin{array}{c}\text { The R } \\
\text { Table }\end{array}$ & Conclusion \\
\hline Economy (X1) & & & & \\
\hline Confidence in doing business for profit (X1.1) & 0,855 & 0,000 & 0,218 & Valid \\
Motivation to get profit (X1.2) & 0,844 & 0,000 & 0,218 & Valid \\
\hline Religiosity (X2) & & & & \\
\hline The ideological dimension (X2.1) & 0,733 & 0,000 & 0,218 & Valid \\
Experience dimension (X2.2) & 0,734 & 0,000 & 0,218 & Valid \\
Consequence dimension (X2.3) & 0,731 & 0,000 & 0,218 & Valid \\
Intellectual dimension (X2.4) & 0,821 & 0,000 & 0,218 & Valid \\
Ritual dimension (X2.5) & 0,815 & 0,000 & 0,218 & Valid \\
\hline Socio-Culture (X3) & & & & \\
\hline Potential demographics (X3.1) & 0,861 & 0,000 & 0,218 & Valid \\
Community lifestyle patterns (X3.2) & 0,903 & 0,000 & 0,218 & Valid \\
\hline Regulation(X4) & & & & \\
\hline Awareness of the law (X4.1) & 0,778 & 0,000 & 0,218 & Valid \\
\multicolumn{1}{c}{ Jurnal Ilmiah Ekonomi Islam, ISSN: 2477-6157; E-ISSN 2579-6534 } & \\
\hline
\end{tabular}




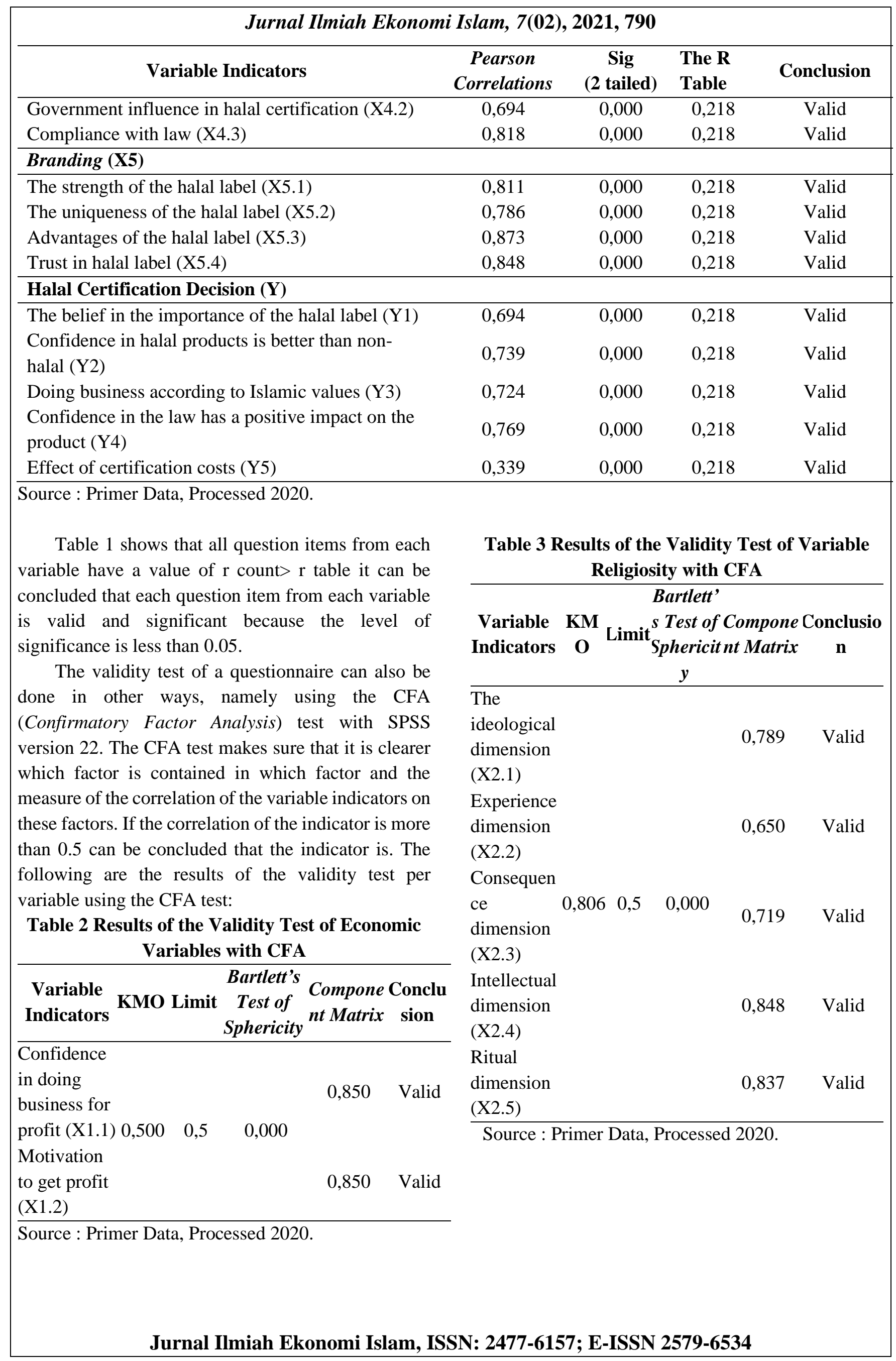


Jurnal Ilmiah Ekonomi Islam, 7(02), 2021, 791

Table 4 Results of the Validity Test of SocioCultural Variables with CFA

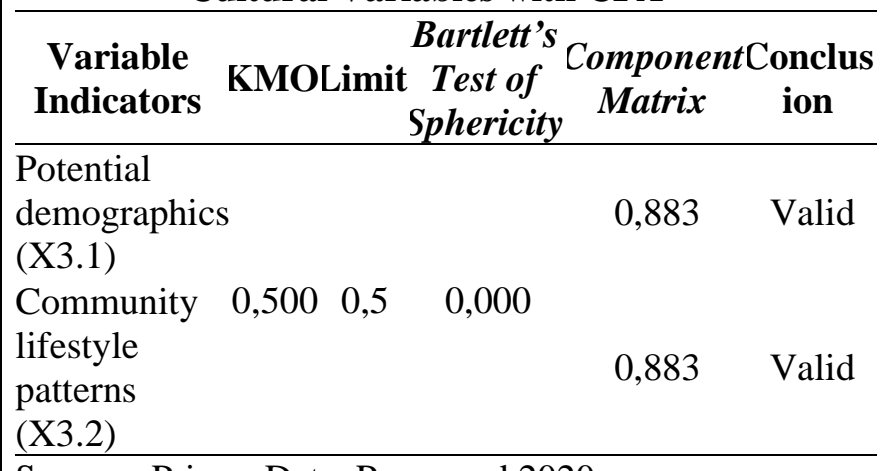

Source : Primer Data, Processed 2020.

Table 5 Results of the Regulatory Variable Validity Test with CFA

\begin{tabular}{l}
\hline \multicolumn{1}{c}{$\begin{array}{c}\text { Bartlett' } \\
\text { Variable } \\
\text { Indicators }\end{array}{ }^{\text {KMOLimit of Compone Conclusio }}$} \\
Sphericit nt Matrix \\
$y$
\end{tabular}

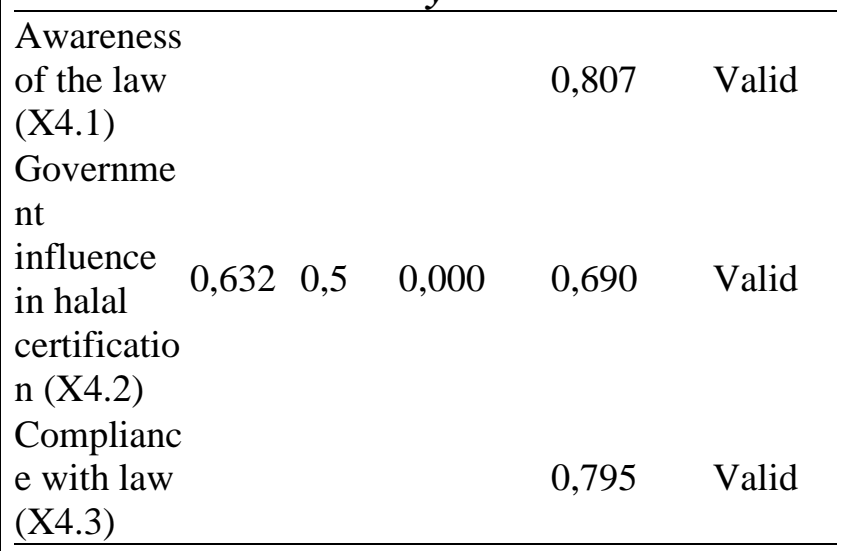

Source : Primer Data, Processed 2020.

Table 6 Results of the Validity Test of Branding Variables with CFA

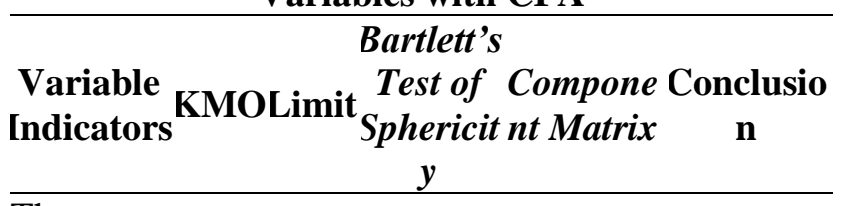

The

strength of

the halal

label

$0,815 \quad$ Valid

(X5.1)

The

uniquenes

s of the $\quad 0,779 \quad$ Valid

halal label $0,800 \quad 0,5 \quad 0,000$

(X5.2)

Advantage

$\mathrm{s}$ of the

halal label

$0,892 \quad$ Valid

(X5.3)

Trust in

halal label

(X5.4)

Source : Primer Data, Processed 2020.
Table 7 Results of the Validity Test of the

Decision Variable on Halal Certification with CFA

Bartlett's

Variable KMOLimit Test of Compone Conclusio Indicators ${ }^{\text {Sphericit nt Matrix n }}$ $y$

The belief

in the

importanc

e of the

$0,743 \quad$ Valid

halal label

(Y1)

Confidenc

e in halal

products is

better than

$0,842 \quad$ Valid

non-halal

(Y2)

Doing

business

$\begin{array}{lllll}\text { according } & 0,763 & 0,5 & 0,000 & 0,784\end{array}$ Valid

values

(Y3)

Confidenc

$\mathrm{e}$ in the

law has a

positive

impact on

0,794 Valid

the

product

(Y4)

Effect of

certificatio

$n$ costs

0,972 Valid

(Y5)

Source : Primer Data, Processed 2020.

Based on the validity test using the CFA, the results showed that all variables obtained KMO value was 0.763 more than the minimum limit and the value of Bartlett's Test of Sphericity was significant below 0.05 so that it could be continued for further tests. All values of the component matrix indicator variable for the halal certification decision are more than 0.5 so that they can be declared valid.

The reliability test was conducted to see whether the questionnaire used was reliable or not by looking at the respondents' consistent answers from time to time. The variable is said to be reliable if the Cronbach Alpha value is> 0.6. The following are the results of the questionnaire reliability test in this study: 
Jurnal Ilmiah Ekonomi Islam, 7(02), 2021, 792

Tabel 8 Reliability Test Results

\begin{tabular}{lccc}
\hline \multicolumn{1}{c}{ Variable } & $\begin{array}{c}\text { Cronbach } \\
\text { Alpha }\end{array}$ & $\begin{array}{c}\text { Standard } \\
\text { Alpha }\end{array}$ & Conclusion \\
\hline Economics (X1) & 0,615 & 0,6 & Reliable \\
Religiosity (X2) & 0,812 & 0,6 & Reliable \\
Socio-Culture & 0,710 & 0,6 & Reliable \\
(X3) & 0,642 & 0,6 & Reliable \\
Regulation (X4) & 0,844 & 0,6 & Reliable \\
Branding (X5) & 0,840 & Reliable \\
Halal Certification & 0,616 & 0,6 & \\
Decision (Y) & & & \\
\hline
\end{tabular}

Source : Primer Data, Processed 2020.

Table 8 shows that the results of the reliability test have obtained the Cronbach Alpha values of variables $\mathrm{X} 1, \mathrm{X} 2, \mathrm{X} 3, \mathrm{X} 4, \mathrm{X} 5$, and $\mathrm{Y}$ which are greater than the standard alpha (0.6), which means that all variables in this study are reliable so that they can be continued to carry out the test next.

\section{Classic assumption test}

\section{Normality test}

The normality test is a test that aims to determine whether the regression model of the independent and dependent variables has a normal distribution or not. The data distribution is said to be normally distributed. It can be verified using a histogram, a normal probability plot, and one sample KolmogorovSmirnov. The results of the normality test are as follows:

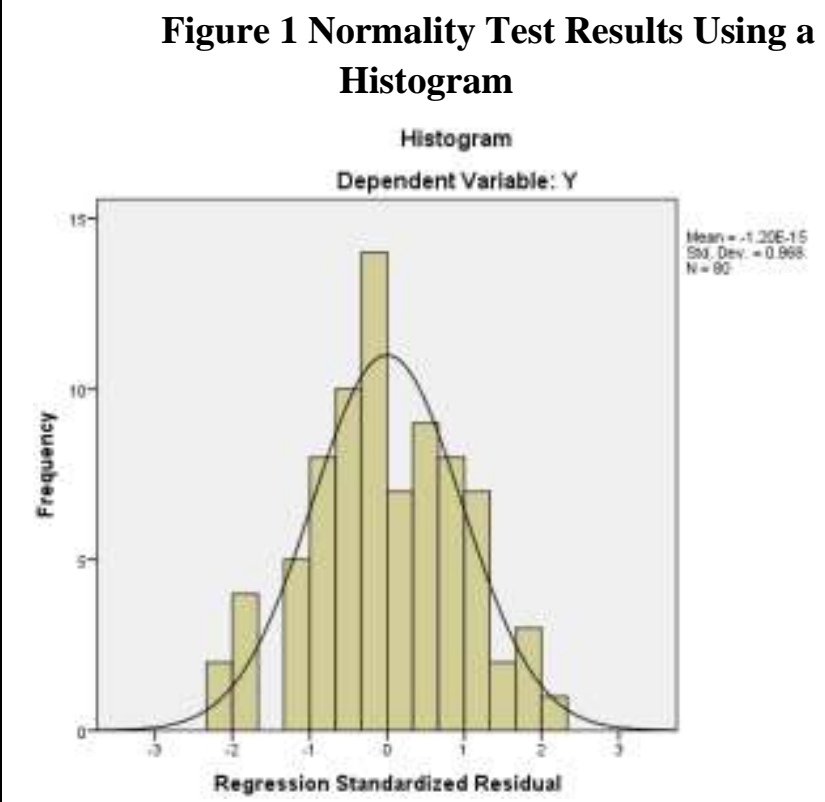

Source : Primer Data, Processed 2020.
Figure 2 Normality Test Results Using the Normal P-Plot

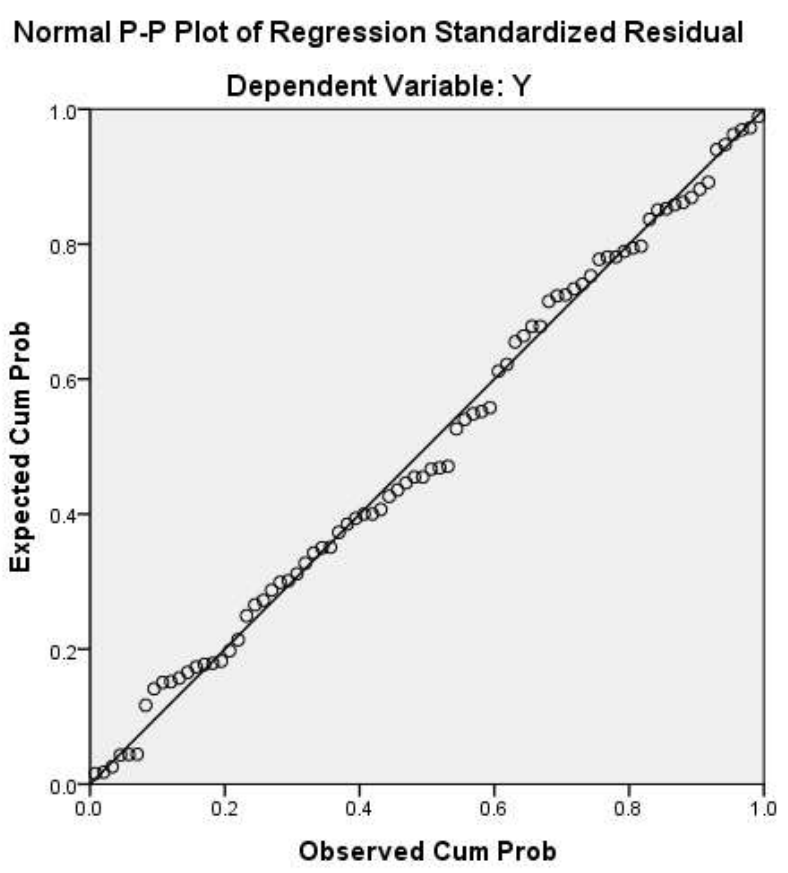

Source : Primer Data, Processed 2020.

Table 9 Normality Test Results Using One Sample Kolmogorov-Smirnov

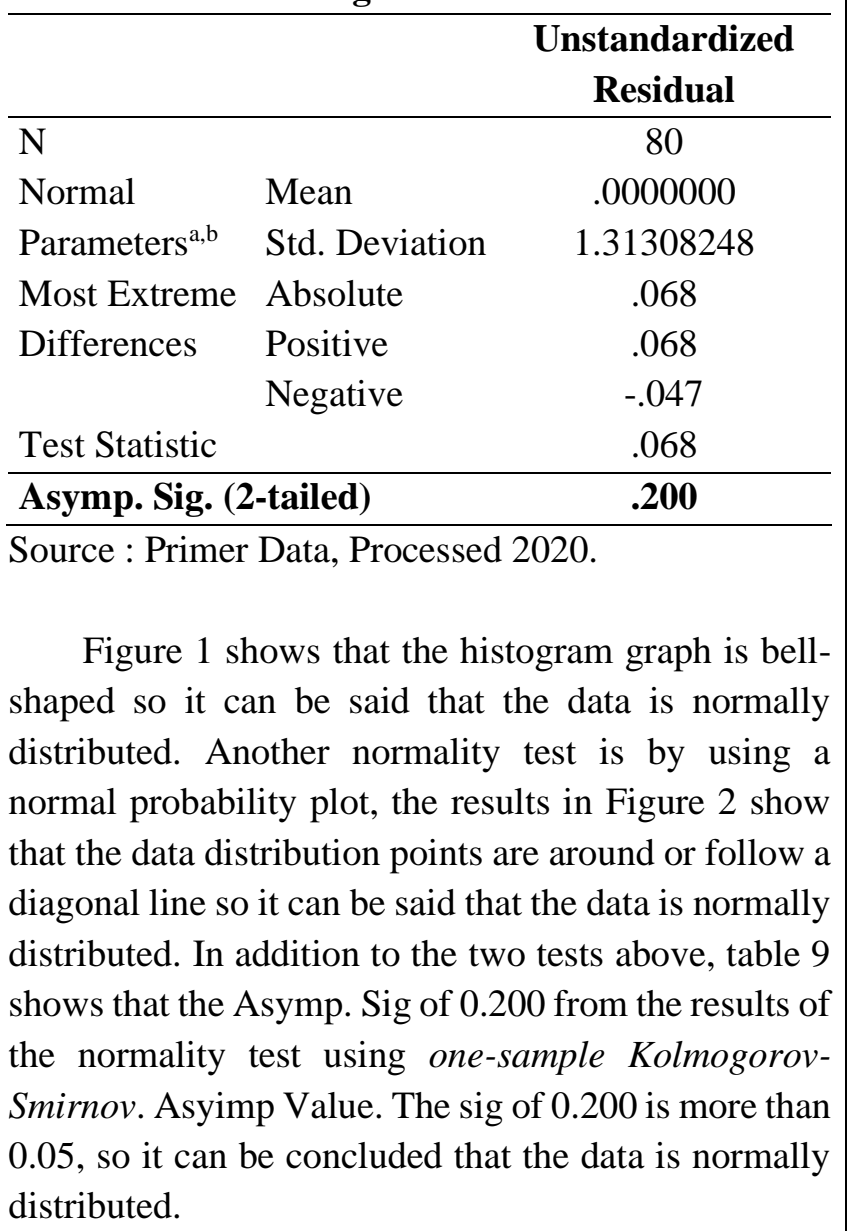




\section{Multicollinearity Test}

A Multicollinearity test is used to test whether in a regression model there is a correlation between independent variables. The way to detect a regression model is multicollinearity or cannot be seen from the Variance Inflation Factor (VIF) value and tolerance value. The following are the results of the multicollinearity test:

Table 9 Multicollinearity Test Results

\begin{tabular}{|c|c|c|c|}
\hline Variable & Tolerance & VIF & Conclusion \\
\hline $\begin{array}{l}\text { Economics } \\
(\mathrm{X} 1)\end{array}$ & 0,767 & 1,304 & $\begin{array}{c}\text { Multicollinearity does } \\
\text { not occur }\end{array}$ \\
\hline $\begin{array}{l}\text { Religiosity } \\
\text { (X2) }\end{array}$ & 0,563 & 1,776 & $\begin{array}{l}\text { Multicollinearity does } \\
\text { not occur }\end{array}$ \\
\hline $\begin{array}{l}\text { Socio- } \\
\text { Culture } \\
\text { (X3) }\end{array}$ & 0,656 & 1,524 & $\begin{array}{l}\text { Multicollinearity does } \\
\text { not occur }\end{array}$ \\
\hline $\begin{array}{l}\text { Regulation } \\
\text { (X4) }\end{array}$ & 0,828 & 1,208 & $\begin{array}{l}\text { Multicollinearity does } \\
\text { not occur }\end{array}$ \\
\hline $\begin{array}{l}\text { Branding } \\
\text { (X5) }\end{array}$ & 0,557 & 1,795 & $\begin{array}{l}\text { Multicollinearity does } \\
\text { not occur }\end{array}$ \\
\hline
\end{tabular}

Source : Primer Data, Processed 2020.

Table 10 shows that the tolerance value for all independent variables is greater than 0.1 and the VIF value of all independent variables is less than 0.10 , which means that there is no multicollinearity between the independent variables.

\section{Heteroscedasticity Test}

A heteroscedasticity test was performed to test a regression model where there is an inequality of variance from one residual of one observation to another. Knowing a regression model that does not have heteroscedasticity is to use a scatterplot chart and the Glejser test. The following are the results of the heteroscedasticity test with a scatterplot and glejser:

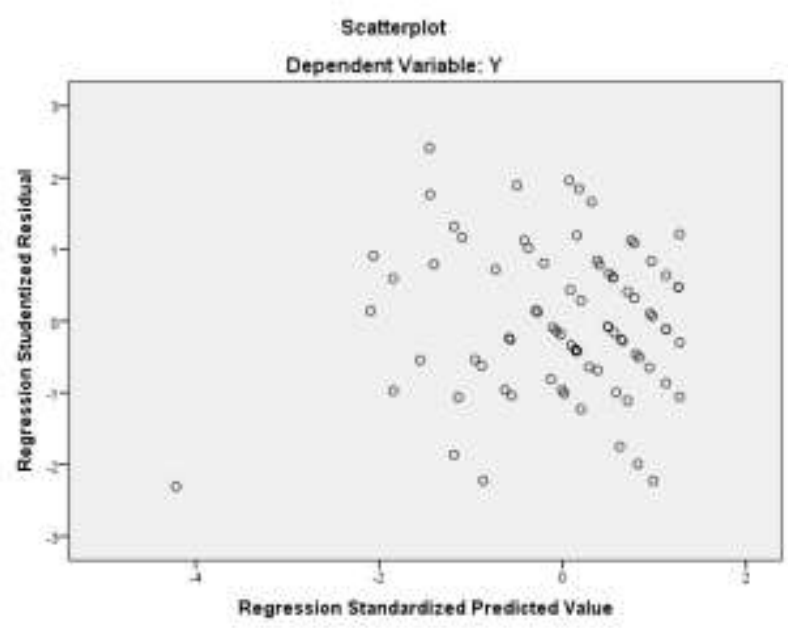

Figure 3 Heteroscedasticity Test Results Scatterplot
Table 11 Heteroscedasticity Test Results - Glejser

\begin{tabular}{|c|c|c|}
\hline Variable & Sig. & Conclusion \\
\hline Economics (X1) & 0,368 & $\begin{array}{l}\text { Heteroscedasticity does not } \\
\text { occur }\end{array}$ \\
\hline Religiosity (X2) & 0,769 & $\begin{array}{l}\text { Heteroscedasticity does not } \\
\text { occur }\end{array}$ \\
\hline $\begin{array}{l}\text { Socio-Culture } \\
\text { (X3) }\end{array}$ & 0,267 & $\begin{array}{l}\text { Heteroscedasticity does not } \\
\text { occur }\end{array}$ \\
\hline Regulation (X4) & 0,121 & $\begin{array}{l}\text { Heteroscedasticity does not } \\
\text { occur }\end{array}$ \\
\hline Branding (X5) & 0,266 & $\begin{array}{l}\text { Heteroscedasticity does not } \\
\text { occur }\end{array}$ \\
\hline
\end{tabular}

Source : Primer Data, Processed 2020.

The results of the heteroscedasticity test with a scatterplot in figure 3 show that the data is spread above and below the number 0 on the $\mathrm{Y}$-axis, and does not form a certain pattern so that it can be concluded that there is no multicollinearity. Furthermore, in table 11 the results of the heteroscedasticity test using the Glejser method show that the significance value of all independent variables is more than 0.05 , which means that there is no multicollinearity in the regression model.

\section{Multiple Regression Analysis}

Multiple linear regression analysis aims to analyze the effect of the independent variable on the dependent variable. This multiple linear regression analysis is to see how much influence the independent variables in this study are: economy (X1), religiosity (X2), socio-culture (X3), regulation (X4), and branding (X5) on the dependent variable, namely the decision of halal certification. . The following are the results of multiple linear regression tests:

Table 4 Multiple Regression Analysis Test Results

\begin{tabular}{|c|c|c|c|c|c|}
\hline \multirow[t]{2}{*}{ Model } & \multicolumn{2}{|c|}{$\begin{array}{c}\text { Unstandardiz } \\
\text { ed } \\
\text { Coefficients }\end{array}$} & $\begin{array}{c}\text { Standardized } \\
\text { Coefficients }\end{array}$ & \multirow[t]{2}{*}{$\mathbf{t}$} & \multirow[t]{2}{*}{ Sig. } \\
\hline & B & $\begin{array}{l}\text { Std. } \\
\text { Error }\end{array}$ & Beta & & \\
\hline 1 (Constant) & 2.336 & 1.355 & & 1.724 & .089 \\
\hline $\mathrm{X} 1$ & .024 & .142 & .014 & .170 & .866 \\
\hline $\mathrm{X} 2$ & .272 & .076 & .345 & 3.577 & .001 \\
\hline $\mathrm{X} 3$ & .152 & .164 & .083 & .927 & .357 \\
\hline $\mathrm{X} 4$ & .243 & .102 & .189 & 2.373 & .020 \\
\hline $\mathrm{X} 5$ & .393 & .104 & .366 & 3.784 & .000 \\
\hline
\end{tabular}

Source : Primer Data, Processed 2020.

Table 4 shows the multiple linear regression equation model in this study as follows:

Source : Primer Data, Processed 2020. 
$\mathrm{Y}=0,014 \mathrm{X} 1+0,345 \mathrm{X} 2+0,083 \mathrm{X} 3+0,189 \mathrm{X} 4+0,366 \mathrm{X} 5+\mathrm{e}$

Information :

$\mathrm{Y}=$ Halal Certification Decision

$\mathrm{A}=$ Constant

$\mathrm{X} 1$ = Economy

$\mathrm{X} 2$ = Religiosity

$\mathrm{X} 3$ = Socio-Culture

$\mathrm{X} 4=$ Regulation

$\mathrm{X} 5=$ Branding

$\mathrm{e}=$ Error

The results of the multiple linear regression test above can be interpreted as follows:

a. The coefficient of economic variables (X1) is 0.014. The interpretation of these results is that economic variables have a positive influence on the decision of halal certification so that the economic motivation of MSME players is high, making their intention to make halal certification decisions increase. This is true with the assumption that other variables are fixed (unchanged).

b. The coefficient of the religiosity variable (X2) is 0.345 . The interpretation of these results is that the variable of religiosity has a positive influence on the decision of halal certification so that if MSMEs are increasingly religious, there will be an increase in the intention of MSME players to make halal certification decisions. This is true with the assumption that other variables are fixed (unchanged).

c. The coefficient of socio-cultural variables (X3) is 0.083 . The interpretation of these results is that the socio-cultural variables have a positive influence on the decision of halal certification so that if the social and cultural values that become the lifestyle in the environment of MSMEs are getting stronger, the increasing intention of MSME players to make decisions on halal certification, MSMEs will increasingly want to make certification decisions. halal. This is true with the assumption that other variables are fixed (unchanged).

d. The coefficient of the regulatory variable (X4) is 0.107 . The interpretation of these results is that regulatory variables have a positive influence on halal certification decisions so that regulations are getting tighter, increasing the intention of MSME players to make halal certification decisions. This is true with the assumption that other variables are fixed (unchanged). e. The coefficient of the branding variable (X5) is 0.390 . The interpretation of these results is that the branding variable has a positive influence on the decision of halal certification so that if the halal label makes the branding of MSME products increases, the intention of MSMEs players to make halal certification decisions will increase. This is true with the assumption that other variables are fixed (unchanged).

Based on the multiple linear regression equation, it shows that all independent variables, namely economy (X1), religiosity (X2), socio-culture (X3), regulation (X4), and branding (X5) have a positive effect on the halal certification decision of MSME actors. The branding variable is the variable that has the most dominant influence on the halal certification decision variable $(\mathrm{Y})$. This is because the coefficient value of the branding variable (X5) has the highest value compared to other independent variables which afterward is followed by the religiosity variable (X2), regulatory variable (X4), socio-cultural variable (X3), and economic variable (X1).

\section{Partial Test}

The $\mathrm{t}$ test is a test to determine whether the independent variables, namely economy, religiosity, socio-culture, regulation, regulation, and branding individually on the dependent variable, namely the decision on halal certification. The basis for decision making using the $t$ test is as follows:

1. If $t$ count $>t$ table with a significance value $<0.05$, then Ho is rejected and Ha is accepted.

2. If $\mathrm{t}$ count $<\mathrm{t}$ table with a significance value $>$ 0.05 , then Ho is accepted and Ha is rejected.

The basis for the above collection requires t table and $t$ count. The following are the results of the $t$ test:

Equation 1 T-Table Formula

t tabel $=\left(\frac{\alpha}{2} ; n-k-1\right)=\left(\frac{0,05}{2} ; 80-5-1\right)=(0,025 ; 74)=1,99254$

Table 12 Results of the $t$-test

\begin{tabular}{lcc}
\hline \multicolumn{1}{c}{ Independent Variable } & t-test & Sig. \\
\hline Economics (X1) & 0,170 & 0,866 \\
Religiosity (X2) & 3,577 & 0,001 \\
Socio-Culture (X3) & 0,927 & 0,357 \\
Regulation (X4) & 2,373 & 0,020 \\
Branding (X5) & 3,784 & 0,000 \\
\hline
\end{tabular}

Source : Primer Data, Processed 2020. 
Based on the results of the t-test, the results are in the form of $t$ count and significant values in table 12 and the calculation of $t$ table in equation 1 , the explanation is as follows:

a. The Influence of Economic Variables (X1) on Halal Certification Decisions

The economic variable has a $t$ value of 0.170 and a significance value of 0.866 . The $t$ value of the economic variable is smaller than the $t$ table which is 1.99254 and the significance value is bigger than 0.05 , so it can be concluded that the variable $\mathrm{X} 1$ does not affect the dependent variable, which means that $\mathrm{H} 1$ is rejected.

b. The Influence of Variable Religiosity (X2) on Halal Certification Decisions

The religiosity variable has a $t$ value of 3.577 and a significance value of 0.001 . The $t$ value of the religiosity variable is greater than the $t$ table which is 1.99254 and the significance value is smaller than 0.05 , so it can be concluded that the variable $\mathrm{X} 2$ has an effect on the dependent variable and the effect is positive and significant, which means that $\mathrm{H} 2$ is accepted.

c. The Influence of Socio-Cultural Variables (X3) on Halal Certification Decisions

The socio-cultural variable has a t value of 0.927 and a significance value of 0.357 . The $t$ value of the socio-cultural variable is smaller than the $t$ table which is 1.99254 and the significance value is greater than 0.05 , so it can be concluded that the variable $\mathrm{X} 3$ does not affect the variable, which means that $\mathrm{H} 3$ is rejected.

d. The Influence of Regulatory Variables (X4) on Halal Certification Decisions

The regulatory variable has a $t$ value of 2.373 and a significance value of 0.020 . The $t$ value of the regulatory variable is greater than the $t$ table which is 1.99254 and the significance value is smaller than 0.05 , so it can be concluded that the variable $\mathrm{X} 4$ has an effect on the dependent variable and the effect is positive and significant, which means that $\mathrm{H} 4$ is accepted.

e. The Influence of Variable Branding (X5) on Halal Certification Decisions

The branding variable has a t value of 3.784 and a significance value of 0.000 . The $t$ value of the branding variable is greater than the table which is 1.99254 and the significance value is less than 0.05 , so it can be concluded that the variable X5 has an effect on the dependent variable and the effect is positive and significant, which means that H5 is accepted.

\section{Simultaneous Test}

The $\mathrm{F}$ test aims to determine whether the independent variables simultaneously or simultaneously influence the dependent variable. The $\mathrm{F}$ test is done by comparing the $\mathrm{F}$ count with the $\mathrm{F}$ table, as well as the significance value. The basis for decision making using the t-test is as follows:

1. If $F$ count $>t$ table with a significance value $<0.05$, then Ho is rejected and Ha is accepted.

2. If $\mathrm{F}$ count $<\mathrm{t}$ table with a significance value $>$ 0.05 , then Ho is accepted and Ha is rejected.

The basis for the above collection requires an $\mathrm{F}$ table and $\mathrm{F}$ count. The following are the results of the $F$ test:

Equation 2 F-Table Formula

F tabel $=(k ; n-k)=(5 ; 80-5)=(5 ; 75)=2,34$

Tabel 10 Results of The F-Tests

\begin{tabular}{ccc}
\hline Model & F-test & Sig. \\
\hline Regression & 23,489 & 0,000
\end{tabular}

Source : Primer Data, Processed 2020

Based on the results of the $F$ test which results in the form of $F$ count and the significant value in table 13 and the calculation of $\mathrm{F}$ table in equation 2, then the explanation is the calculated $F$ value of 23.489 and the significance value of 0.000 , it can be concluded that $\mathrm{F}$ count is greater than $\mathrm{F}$ table which is 2.34 and the significance value is less than 0.005 , which means that the independent variables, namely economy (X1), religiosity (X2), socio-culture (X3), regulation (X4), and branding (X5) simultaneously have a positive effect on the dependent variable, namely the decision of halal certification. H7 accepted.

\section{Determination Coefficient Test}

The coefficient of determination (R2) test is used to measure how far the model explains the dependent variable. The range of adjusted $R 2$ values is $0-1$. The small adjusted $R 2$ value indicates that the ability of the independent variable to explain the dependent variable is very limited. If the adjusted $R 2$ value is almost close to 1 , then the independent variable can provide almost all the information needed to explain the dependent variable. The following is the result of the coefficient of determination: 
Table 14 Determination Coefficient Test Results

\begin{tabular}{ccccc}
\hline Model & $\mathbf{R}$ & $\begin{array}{c}\text { R } \\
\text { Square }\end{array}$ & $\begin{array}{c}\text { Adjusted R } \\
\text { Square }\end{array}$ & $\begin{array}{c}\text { Std. Error of } \\
\text { the Estimate }\end{array}$ \\
\hline 1 & $.783^{\mathrm{a}}$ & .613 & .587 & 1.357 \\
\hline
\end{tabular}

Source : Primer Data, Processed 2020

Table 14 shows that the value of the coefficient of determination used is the Adjusted $R$ Square value because it is a normalized value. The adjusted R2 value is 0.587 or $58.7 \%$, which means that the economic variables (X1), religiosity (X2), socioculture (X3), regulation (X4), and branding (X5) simultaneously affect the halal certification decision variable by $58,7 \%$. While the remaining $41.3 \%$ is explained by other variables outside the regression model of this study.

\section{CONCLUSION}

This study aims to see the effect of economy, religiosity, socio-culture, regulation and branding on certification decisions partially and simultaneously. Based on the results and discussion in the previous chapter, the following conclusions can be drawn :

a. The economy does not have a partial effect on the decision of MSME players to carry out halal certification. This is because halal certification is facilitated free of charge by the Tangerang City Government so that MSMEs do not consider making an analysis of the benefits to be achieved or calculating the costs incurred, because the most important thing for MSMEs is how to get halal certification for free due to limited quota. However, for a Muslim profit as a worldly form is not the only goal in doing business.

b. Religiosity has a partially positive effect on the decisions of MSME actors to carry out halal certification. This is because the religious knowledge possessed by MSMEs makes them obliged to carry out halal certification. Halal certification for UMKM actors is also a form of worship to get a reward for themselves. In addition, MSME players believe that halal certification is an obligation.

c. Socio-culture has no partial effect on the decision of MSME actors to carry out halal certification. This is because, following the Tangerang City motto, Akhlakul Karimah, the community highly upholds the value of Islam in their daily lives so that MSME actors feel that the majority of people are Muslim and the Islamic lifestyle is not an object of the reason for halal certification but has become a belief. MSME actors personally believe that halal certification is their obligation as a Muslim.

d. Regulations have a partially positive effect on the decisions of MSME players to carry out halal certification. This is because SMEs are aware of the applicable laws and are strict in their implementation because they only require that products that can be circulated are products that have been certified halal. The role of government is the most important for MSME players because it can provide free halal certification assistance with the Regional Budget (APBD).

e. Branding has a partially positive effect on the decision of MSME players to carry out halal certification. This is because, with the existence of a halal label, UMKM products are trusted as well as a characteristic that differentiates them from products that are not certified halal. In addition, the halal label is a strength to make consumers more loyal and a better brand image.

f. The independent variables in this study which consist of economic, religiosity, socio-cultural, regulatory, and branding variable have a positive effect simultaneously on the decision of MSME actors to carry out halal certification. The independent variable of this study has an effect of $58.7 \%$, which means that it can explain the reasons for MSME actors to carry out halal certification.

\section{REFERENCE}

Ali, M. (2016). Konsep Makanan Halal dalam Tinjauan Syariah dan Tanggung Jawab Produk Atas Produsen Industri Halal. AHKAM : Jurnal Ilmu Syariah, 16(2), 291-306.

Astogini, D., Wahyudin, \& Wulandari, S. Z. (2011). Aspek Religiusitas dalam Keputusan Pembelian Produk Halal. Jeba, 13(1), 1-8.

Badan Kebijakan Fiskal. (2019). Tinjauan Ekonomi, Keuangan, \& Fiskal Edisi IV.

Dinas Koperasi dan UKM Provinsi Banten. (2018). Jumlah Usaha Mikro, Kecil, dan Menengah Menurut Kabupaten/Kota di Provinsi Banten Tahun 2018.

Fatmasari Sukesti, \& Mamdukh Budiman. (2014). the Influence Halal Label and Personal Religiousity on Purchase. International Journal of Business, Economics and Law, 4(1), 2012-2015. 
Jurnal Ilmiah Ekonomi Islam, 7(02), 2021, 797

Hanim Yusuf, A., Abdul Shukor, S., \& Salwa Ahmad Bustamam, U. (2016). Halal Certification vs Business Growth of Food Industry in Malaysia. Journal of Economics, Business and Management, 4(3), 247-251.

Iwan Zainul Fuad. (2010). Kesadaran Hukum Pengusaha Kecil Di Bidang Pangan Dalam Kemasan Di Kota Semarang Terhadap Regulasi Sertifikasi Produk Halal. In E-Journal Undip (Vol. 9, Issue 1). Universitas Diponegoro.

KEMENKOPUKM. (2018). Perkembangan Data Usaha Mikro , Kecil, Menengah Dan Usaha Besar. Www.Depkop.Go.Id.

Marzuki, S. Z. S., Hall, C. M., \& Ballantine, P. W. (2012). Restaurant managers' perspectives on halal certification. Journal of Islamic Marketing, $3(1), 47-58$.
Nursinta Harmaniar. (2016). Pengaruh Gaya Hidup, Promosi dan Demografi terhadap Keputusan Membeli Smartphone Blacberry. Tazkiya Journal of Psychology, 04, 117-128.

Rajagopal, S., Ramanan, S., Visvanathan, R., \& Satapathy, S. (2011). Halal certification: Implication for marketers in UAE. Journal of Islamic Marketing, 2(2), 138-153.

Susila, A. R. (2013). Potensi Ekonomi Daerah Dalam Pengembangan Umkm Unggulan Di Kota Tangerang. 1-9.

Waluyo, W. (2013). Pengaruh Pemahaman Agama, Motifasi Mendapatkan Profit Dan Tingkat Pendidikaan Terhadap Kesadaran Sertifikasi Halal Bagi Produsen Makanan Di Kabupaten Sleman Dan Bantul. Inferensi, 7(1), 75. 